\title{
ISLAMIC BIOETHICS OF PAIN MEDICATION: AN EFFECTIVE RESPONSE TO MERCY ARGUMENT
}

\section{Mohammad Manzoor Malik}

Assistant Professor

Department of General Studies

Kulliyyah of Islamic Revealed Knowledge and Human Sciences, International Islamic University Malaysia E-mail: philomalik@iium.edu.my / philomalik@gmail.com

ABSTRACT: Pain medication is one of the responses to the mercy argument that utilitarian ethicists use for justifying active euthanasia on the grounds of prevention of cruelty and appeal to beneficence. The researcher reinforces the significance of pain medication in meeting this challenge and considers it the most preferred response among various other responses. It is because of its realism and effectiveness. In exploring the mechanism and considerations related to pain medication, the researcher briefly touches the Catholic ethical position on the issue, a position that cannot be ignored in the development of contemporary bioethics. The researcher particularly deliberates on the contemporary Islamic discourse on the issue; by furthering the debate in line with the Islamic legal maxims and general guidance from the primary sources of Islamic law and ethics. The resolution on the issue is sought by synthesizing the views and legal maxims (al-Qawaid al-Fiqhiyyah) on the issue, which in conclusion provide justification for pain medication by considerably regarding pain as "necessity" and "pressing need". However, such resolution allows pain medication to the limit and proportion that removes the pain and prohibits overdosing the patient with medication that may directly cause the death.

Key Words: Mercy argument, euthanasia, pain medication, doctrine of double effect, Islamic bioethics

INTRODUCTION: Mercy argument is at the heart of discussions that support legalizing active euthanasia. Various versions of the argument defend permissibility of mercy killing by highlighting essential aspects related to patients and the nature of medication. In brief, the argument is used to justify mercy killing of the patients who request so on the grounds of avoiding unnecessary pain and suffering. After exploring the mercy argument and briefly mentioning the popular responses against it, I would argue that among these responses, pain medication is the most effective solution and the best response because it helps in coping with the pain and suffering of the patients and avoids active euthanasia. Most importantly, this solution is realistic as it does not ignore the actual harm of pain that some patients suffer because of serious diseases. In understanding the ways this pain medication is suggested to be implemented, Catholic ethical position on the subject is briefly mentioned to show its importance in Western bioethics, thus showing its similarity with Islamic discourse. The crucial part of the article deliberates with adequate discussion on formulation of Islamic position on pain medication within the contemporary discourse on the issue that is in line with the legal maxims and general guidance from the primary sources of Islamic law and ethics. 
Mercy Argument for Active Euthanasia: Mercy argument is among a few powerful arguments that proponents of euthanasia make and it is "central to the libertarian viewpoint" ${ }^{1}$. It is based on prevention of cruelty and it appeals to the principle of beneficence. According to this argument "it is cruel and inhumane to refuse the plea of a terminally ill person that his or her life be mercifully ended in order to avoid unnecessary suffering and pain" ${ }^{2}$. Utilitarian moral philosophers such as Peter Singer, John Harris, Marvin Kohl, and Jonathan Glover have arguably defended this argument on the consequential basis.

The same argument is restated by James Rachels; he believes that the single most powerful argument in support of euthanasia is the argument from mercy. He claims that, it is also an exceptionally simple argument, at least in its main idea, which makes one uncomplicated point that terminal patients sometimes suffer pain so horrible that it is beyond the comprehension of those who have not actually experienced it. Their suffering can be so terrible that we do not like even to read about it or think about it; we recoil even from the descriptions of such agony. The argument from mercy says: euthanasia is justified because it provides an end to that ${ }^{3}$. However, to what extent this argument can appeal is very succinctly described by Ruth Chadwick as follows:

"This argument is used not just in relation to actual physical suffering, but also mental suffering, the frustration of being unable to perform everyday tasks for oneself, and the erosion of dignity as personal and previously private tasks have to be performed by someone else as one reverts to behavior not experienced since infancy. The argument from beneficence or utilitarianism will be strongest where there is no alternative but death to the misery that one is witnessing, both when the period of suffering is likely to be unremitting and prolonged or when death is fairly imminent"4.

Popular Criticisms of Mercy Argument: The responses to mercy argument are various. J. P. Moreland and Norman L. Geisler believe that the critics have made responses at least in four ways. First, there are very few cases where modern medicine cannot alleviate suffering and pain, building an ethical doctrine on such few cases is not a right moral methodology. Second, suffering as itself is not a bad thing; it has many positive aspects. Third, instead of killing in severe circumstances, pain medication could be done even it causes death as an unintended effect. Four, life is like a gift and human beings are not the absolute owners of their lives ${ }^{5}$.

Defense of Pain Medication against Mercy Argument: Among the above counter arguments, the most important argument in my view is that which proposes pain medication as a solution to pain and suffering. Though other arguments have their meaning and significance, however, if a patient is not to be killed, the patient deserves to live painlessly; pain and suffering are real harm. There is no other way but to resort to pain medication if severe and unbearable pain of patients is to be removed. Arguments that downplay pain that many ill people suffer are made by people who I think have never suffered the acute pain or fail to estimate rightly the intensity of the pain that occur in some diseases. The realism regarding terminally ill patients is that some of them do go through a lot of pain and between killing them and pain medication, the choice which stays on life saving side is, indeed, pain medication. With highly effective painkillers, now 
available, great pain that terminally ill patients suffer could be prevented. Therefore, use of painkillers, not euthanasia, is the answer to painful terminal illness. However, enhancing pain medication management is in need of a continuous effort because "[I]n up to 90 percent of [cancer] patients, the pain can be controlled by relatively simple means. Nevertheless, under treatment of cancer pain is common because of clinicians' inadequate knowledge of effective assessment and management practices, negative attitudes of patients and clinicians toward the use of drugs for the relief of pain, and a variety of problems related to reimbursement for effective pain management" 6 .

On the basis of mercy argument, in a restrict sense, when the case is related to terminally ill patients, proponents of active euthanasia argue that the patients whose death is foreseen instead of killing them they are left to die and their dying process takes days and weeks in suffering, such patients could have been better off by active euthanasia by putting end to their suffering. Against this thinking, I argue in two ways. The first is that pain killers coupled with efficient palliative care help minimizing unbearable pain and save people from committing to act of killing which is an undesirable solution on many grounds and an option disfavored by majority cultures and countries of the present world. The second is that for those patients who are terminally ill and their life may be miserable due to the pain which is caused by illness, removing their immediate harm should be first priority; therefore, providing pain medication to such patients in a careful manner without crossing the appropriate bounds by overdosing them ought to be allowed, even that may have side effects leading to hastening death as an unintended consequence.

Pain medication has been regarded by Catholic and Islamic bioethicists as a solution and right alternative to active euthanasia while treating painful, suffering terminally ill patients. In Catholic bioethics, the issue is discussed under various applications of Doctrine of Double Effect (DDE). In Islamic writings on the issue, discussions have in various ways tackled issues, some have even rejected such pain medication and some have allowed it without setting any definite guidelines. After some scrutiny of the views, I argue that the discussion in line with the broader guidelines set in the primary sources of Islamic law and ethics i.e. the Quran and Sunnah, the issue could be refined with a decisive stance within a careful discussion that undertakes study of various legal maxims (al-Qawaid al-Fiqhiyyah) relevant to the issue in their applications. The legal maxims retain their due justification because of their derivation from the primary sources of Islam and their widely acceptance as guiding principles in debates wherein their application is invoked such as ethical discussions including the issues related to bioethics. The purpose of discussing Islamic and Catholic positions on the issue of pain medication opens up a venue of dialogue between two ethical traditions which share many common points.

Doctrine of Double Effect (DDE): Catholic Principle for Pain Medication: There are many names for Doctrine of Double Effect (DDE) such as Principle of Double Effect (PDE), Rule of Double Effect (RDE), Double-Effect Reasoning (DER), and simply Double Effect. "The words "double effect" refers to the two effects that an action may produce: the one aimed at, and the one foreseen but in no way desired" ${ }^{7}$. The distinction is between "direct and indirect agency" ${ }^{8}$. Intentions or their lack make moral difference and likewise morality of means that are used to accomplish an act are also considered ${ }^{9}$. The doctrine of double effect holds that there is difference between "what one aims at (one's direct intention) and what is foreseen 
but is not intended (one's oblique intention)" and "it is always wrong to do an action whose intended consequences are bad for the sake of foreseen consequences that are good, but that it may be permissible to perform an action whose intended consequences are good even though the foreseen consequences are bad" ${ }^{10}$.

The principle of double effect beside its various applications in moral issues is of practical significance in many bioethical issues including its use and significance of justifying pain medication. It is one of "the most significant principles proposed by all Catholic medical ethicists"11. Thomas Aquinas is credited with introducing the principle of double effect in his discussion of the permissibility of self-defense in the Summa Theologica ${ }^{12}$. According to him, "nothing hinders one act from having two effects, only one of which is intended, while the other is beside the intention" ${ }^{13}$. The classical formulation of the principle requires fulfillment of four conditions if the action in question is permissible: "(1) The act is good or at least indifferent regarding the end that one directly intends. (2) The good and evil effects follow immediately from the act; that is, the good effect is not obtained by means of the evil effect. (3) One only intends the good effect but merely tolerates the bad effect, even if that bad effect was foreseen prior to the act. (4) There is a proportion between the good and bad effects; that is, the good must be at least equal to the bad" ${ }^{14}$. "Sometimes a fifth condition, "There must be a grave reason for permitting the evil effect" is added, but this is already covered by the third condition. Because it is not possible to avoid all harmful side effects and at the same time to fulfill our obligations to do the good from which these harmful effects also result, we need a principle to guide us in such dilemmas" ${ }^{15}$. In brief, "All authors agree on four conditions to justify an act under the principle of double effect, although all do not follow the same order in proposing the four conditions" ${ }^{16}$.

Thought the doctrine has many applications; in particular, its application in treating terminally ill is widely accepted and traditionally practiced by clinicians. The principle is used to justify the case where a doctor gives drugs to a patient to relieve distressing symptoms even though he knows doing this may shorten the patient's life. This is because the doctor is not aiming directly at killing the patient - the bad result of the patient's death is a side-effect of the good result of reducing the patient's pain. Many doctors use this doctrine to justify the use of high doses of drugs such as morphine for the purpose of relieving suffering in terminally-ill patients even though they know the drugs are likely to cause the patient to die sooner. The double effect doctrine, as applied in medicine, is based on two basic presuppositions: the doctor's motivation is to alleviate suffering; and the treatment must be proportional to the illness. The doctrine applies if 1) the desired outcome is judged to be good e.g., relief of suffering; 2) the bad outcome e.g., death of patient is not intended; 3) the good outcome is not achieved by means of the bad, and 4) the good outcome outweighs the bad $^{17}$. These conditions of the principle are well elaborated on practical grounds by Wanzer et al. (1989/1990); they suggest that in the patient whose dying process is irreversible, the balance between minimizing pain and suffering and potentially hastening death should be struck clearly in favor of pain relief. They recommend that pain medication should be given in whatever dose and by whatever route is necessary for relief. They further suggest that in extreme cases it is morally correct to increase the dose, even though the medication may contribute to the depression of respiration or blood pressure, the dulling of consciousness, or even death, provided the primary goal of the physician is to relieve suffering. They 
suggest that however the proper dose of pain medication is the dose that is sufficient to relieve pain and suffering, even to the point of unconsciousness ${ }^{18}$.

It is therefore an accepted practice to use doctrine of double effect in such cases which contain suffering. Even in cases where death is imminent and pain cannot be minimized or eliminated through normally accepted dosages of medication, active euthanasia is not the only option. A doctor can give the necessary pain medication if the intent is solely to alleviate pain and not to kill, even if it can be foreseen that such an action will hasten death. In this case death is a foreseen, tolerated, but an unintended effect.

Contemporary Islamic Discourse on Pain Medication: Pain medication is one of the new bioethical issues; therefore, discussions on it are contemporary in Islamic writings and no outright guidance on the issue is found in the traditional writings. Generally, pain medication and palliative care is a medication option. The traditional Islamic guidance on medication is based on different opinions of jurists on nature of permissibility of medication in Islam. The discussion is stuffed with many opinions from many jurists based on their (Ijtihad) and preferences of evidences present in the recorded traditions of the Prophet Muhammad called as Hadith and Sunnah. In brief, the conclusions on Islamic stance on medication were made in the resolution that was passed in the seventh session of Majamul fiqh al islami held in Jeddah on 7-12, 11, $1412 \mathrm{~h}$. According to the resolution, medication in light of the Quran and Sunnah is permissible because it guards the self of a person and its protection is one of the aims of Islamic Shariah. However, injunctions regarding medication are types according to cases. Medication is obligatory (wajib) if its abandonment leads to the fatality of the life or an organ or causes its inability or the disease transmits to others such as communicable diseases. Medication is commendable or recommended (mandub) if its abandonment leads to weakness of the body with the abovementioned. It is permissible (mubah) if above two categories are excluded. It is reprehensible (makruh) if by doing medication there is worry of having more trouble than the disease itself that is considered to be cured ${ }^{19}$. However, the statement has not touched pain and suffering of patients who are mostly terminally ill and their pain is sometimes unbearable. Should they do pain medication? Especially, when their pain makes them unable to do the daily functions and leaves them like disabled persons with cries and tears. The traditionalist scholars have not addressed this issue because the issue is itself new. Because of modern advanced developments in medical sciences that lead to development of pain killers that can minimize pain of a patient and in face of emergence of various new diseases and identification of unknown diseases in a rampant manner that cause immense pain to patients, the Islamic response to the issue has become necessary. Therefore, this issue has been discussed by contemporary Muslim scholars and professional bodies concerned with bioethical issues.

The contemporary discourse on pain medication among Muslims is part of fatwas and statements made by scholars. These statements are with both conflicting and complimentary material. Islamic medical codes have concisely touched the issue with indefinite precision.

The fatwas and statements on pain medication are two types. The first type supports prohibition of pain medication that may enhance death and the second type supports permission. The first type disallows pain medication that may hasten death; these fatwas are based on those Prophetic traditions which encourage 
patience with greater reward in hereafter. For example, the Prophet said, "No fatigue, nor disease, nor sorrow, nor sadness, nor hurt, nor distress befalls a Muslim, even if it were the prick he receives from a thorn, but that Allah expiates some of his sins for that" ${ }^{20}$. In addition, these fatwas take justification from the legal maxims that say, "harm is not eliminated by the similar harm" (Ad-dararu la yuzal bi mithlihi). In line with this, some similar fatwas allow pain medication in the general sense that do not mention hastening death even though the medication is based on substances that are prohibited in Islam by taking justification from the legal maxim, "Necessity makes the unlawful lawful" (al-darurat tubih al-mahzurat). The works on legal maxims that are related to their application to bioethical issues mostly written in Arabic have not deliberated on pain medication that is under consideration here.

The second type of fatwas and statements allow pain medication for terminally ill patients, even though it hastens their death, without explaining more on the quality and quantity of medication. For example, the Islamic Code of Medical Ethics, issued by the First International Conference on Islamic Medicine held in Kuwait, in 1981, in its Article Sixty-Two, it states that among "examples of what is not covered by the term "mercy killing" and, therefore, permissible is "The intensified administration of a strong medication to stop a severe pain, although it is known that this medication might ultimately end the patient's life" ${ }^{21}$. In answer to the question, "Should cancer patients' requiring heavy pain medication take the medication or be in pain patiently and remember God", the answer given to the question states : "They must be given pain medication, remember God, and be patient about residual inevitable pain that cannot be relieved medically. A heavy dose of is permitted if necessary provided the intention (niyyah) is not to kill the patient" ${ }^{22}$. Islamic Medical Association of North America (IMANA) also states that terminally ill patients "... should be treated with full respect, comfort measures and pain control" ${ }^{23}$. Hassan Hathout, MD, PhD answers the question “ For a patient who has cancer with bone metastasis and is in constant pain, is it better that he takes strong pain killers all the time or be in pain and remember God?" by stating "He should take pain killers as God does not want him to suffer. In severe pain he may not have the strength to remember God" ${ }^{24}$. Islamic Code of Medical Ethics states, "The claim of killing for painful hopeless illness is also refuted, for there is no human pain that cannot be conquered by medication or by suitable neurosurgery" ${ }^{25}$.

Rationale of Islamic Discourse for Pain Medication: Muslims in regards to bioethical issues turn to Islamic guidance on the related issues and in response to demanding nature of the subject, few medical codes have been drafted, conferences are being organized, and fatwas are being written in response to ever growing new issues and demands of guiding decrees from public on the related matters. From Western Muslim minorities to Eastern majority Muslim countries the fact remains that Muslims as being communities are collectively unanimous on upholding legal, ethical religious sources in resolving the bioethical issues rather than considering seriously any other moral basis of resolution such as utilitarianism or virtue ethics. Some writings by Muslim scholars on bioethical issues are sympathetic to virtue ethics with religious justification that is in line with Western biomedical virtue ethics that includes respect for "autonomy, nonmaleficence, beneficence, and justice" ${ }^{26}$ as expounded by Tom L. Beauchamp and James F.Childress in their pioneer work, Principles of Biomedical Ethics; however, majority works written by Muslim scholars prefer to base their resolutions on original sources of Islam. Therefore, these writings stick to the Islamic juristic methodology (Usul al-Fiqh), both in loose and strict manner, with considerations of the higher 
intentions of Shariah (Maqasid Shari'ah) and applications of some relevant maxims of Islamic laws (alQawaid al-Fiqhiyyah).

Pain medication is among the difficult issues in Islamic bioethics because no clear and direct statement from the Quran and Sunnah on the issue could be stated, except that Islam clearly prohibits killing and suicide. The subject is in need of ljtihad on the issue which vacillates between the clear guidance of Islam on prohibition of killing on one hand and permissibility of removal of harm and difficulty in matters connected to Muslims. Therefore, the case of pain medication has to be understood in the discourse that is conditioned with prohibition of killing and permissibility of removing harm.

Quranic verses on the prohibition of killing are clear and comprehensive in principle. They include: prohibition of killing, prohibition of helping on prohibited acts, consenting to self destruction, and suicide. Regarding the prohibition of killing, the Quran prohibits unjustified killing: "And do not kill anyone whose killing Allah has forbidden, except for a just cause...."27. Furthermore, intentional killing is extremely prohibited: "And whoever kills a believer intentionally, his recompense is Hell to abide therein, and the Wrath and the Curse of Allah are upon him, and a great punishment is prepared for him" ${ }^{28}$. The Quran prohibits resorting to self destruction and suicide: "... And do not kill yourselves (nor kill one another). Surely, Allah is Most Merciful to you" ${ }^{29}$. The Quran prohibits helping and cooperating on conducting sinful acts: "And do not help each other in sin and aggression" ${ }^{30}$. Killing an innocent human being is one of the major sins in Islam. These injunctions derived from the very first source of Islamic guidance and legislation i.e. the Quran clearly prohibit killing, and these injunctions in an aggregated manner prohibit all types of killings.

On the other hand, in cases of pain medication, some patients go through lot of pain which is clear harm. Regarding any kind of misery and harm, Islam encourages its adherents to remove harm and difficulties. The Quran clearly states that "Allah intends for you ease, and does not want to make things difficult for you" ${ }^{31}$; and "Allah does not want to place you in difficulty" ${ }^{32}$.This ease is linked with the weakness that human beings have in their very nature; the Quran states "God desires to lighten things for you, for the human being has been created weak" ${ }^{33}$. In a consistent manner, the Quran shows the manifestation of God's desire to ease as a reality in religious matters, the Quran states "He has chosen you, and has imposed no difficulties on you in religion" ${ }^{34}$. In the similar way, the Prophetic traditions also restate the same message: "Religion is easy..." ${ }^{35}$. Without any doubt, human element of creating ease or difficultness has no role to play in the formulation of issues and injunctions that are clearly stated in the Quran and Sunnah. However, the human nature and its inclination towards difficultness or ease may sometimes inaptly play its role in the process of comprehension and interpretation. Against this possibility, evidences for justification for any decision or position are to be understood in a holistic manner, keeping the overall sprit of Islam in mind, relying on proper methods, and working through evidences in reaching conclusions that seem on scrutiny in line with obviously understandable easy nature of religion. Keeping this in mind, the Prophetic traditions indicate to the probable extrinsic role of human element and desire in understanding nature of religion and the obligations which come with it. The Prophet states "The best of your religion is that which is easiest..." ${ }^{36}$. He further states, "Religion is very easy and whoever overburdens himself in his Religion will not be able 
to continue in that way. So you should not be extremists, but try to be near to perfection and receive the good tidings that you will be rewarded; and gain strength by worshipping in the mornings, the nights" ${ }^{37}$. Therefore, those in position of expounding religion and guiding masses to it have to steer clear on this stance of Islam, the Prophet clearly guides, "Facilitate things to people (concerning religious matters), and do not make it hard for them and give them good tidings and do not make them run away (from Islam)" 38 . The central to the easiness of Islam on removing harm and difficulty is the consideration which God gives to the human capacity, as he clearly states "la yukallifullahu nafsan illa wus'aha", Allah does not burden a person with something more than he can bear ${ }^{39}$.

Islamic Legal Maxims and Pain Medication: Rethinking and Resolution: The doctrine of double effect according to Catholic ethics in regards to pain medication gives a clear premium to intentionality. The Islamic moral principle among maxims of Islamic jurisprudence (al-Qawaid al-Fiqhiyyah) that is close to the matter is (al-umur bi maqasidiha) which means "Matters shall be judged by their objectives" or "Acts are judged by the intention behind them". The principle is without dispute applicable to almost all moral actions. This principle is well founded on the sound tradition of the Prophet in which he states: "Actions are but by intention and each person will have but that which he intended" ${ }^{40}$. However, application of such a principle is not without qualifications when applied to ethical issues. Any adequate qualification of the principle has to be understood in line with other maxims of Islamic jurisprudence. In regards to the issue of pain medication, the qualifying and conjunctive maxims are: "harm shall be removed" (al-darar yuzal); "harm must be eliminated but not by means of another harm" (ad-dararu yuzalu wa lakin la bi-darar); "harm is not eliminated by another harm" (ad-dararu la yuzalu bid-darar); "harm is not eliminated by the similar harm" (Ad-dararu la yuzal bi mithlihi) ; "a greater harm is eliminated by means of a lesser harm" (ad-dararu alashadd yuzal bid-darar al-akhaff); "harm is eliminated to the extent that is possible" (al-darar yuzal bi-qadr al imkan); and "necessity is measured in accordance with its true proportions" (al-darurat tuqaddaru biqadriha). None of these maxims certainly lead to permissibility of pain medication that may result in death; therefore, we find the writings on the issue of applicability of these principles to the pain medication have altogether missed the point. Those who allow pain medication have resorted to other famous maxim i.e. "Necessity makes the unlawful lawful" (al-darurat tubih al-mahzurat); however, their use of the maxim in an unqualified manner is not justifiable.

In seeking a resolution of the issue in light of the broader guidelines of Islamic Shariah and application of Islamic jurisprudential maxims, first of all, the issue of pain medication has to be made clear. To do so, a subject case or problem for pain medication is formulated: suppose a person who is terminally ill or nonterminally ill experiences a great deal of pain that besides creating unbearable pain also renders conducting daily tasks difficult. Patience on enduring such pain is not possible to live with because of the intensified nature of the pain and its hampering a person's ability to conduct daily tasks. Since killing such a person for the alleged reasons of mercy is prohibited on Islamic guidance, whereas, on the other hand, living with pain and suffering is also not possible, the only option that remains open is to carry out pain medication. Using pain medication, on one hand, controls the pain and, on the other hand, it shortens in some cases the life expectancy which comes as a side effect; in other words, it hastens death. To put it another way, there is 
harm and that is pain and removing that harm leads to other harm and that is hastening death. Sometimes overdose of the medication can cause a sudden death.

In resolving the above issue, the question arises: what a Muslim patient and a physician are supposed to do, in compliance with the Islamic bioethical guidance, regarding the matter. When thinking about the case under consideration, there are obviously very important elements which need to be understood properly. They are: hardship (al-ĺaraj); intent (niyyah); and necessity (al-darurat).

In the above-mentioned supposed case the patient undergoes a severe pain which could not be removed unless pain medication is applied, the juristic maxim "Hardship shall bring alleviation", (al-mashaqqatu tajlib al-tayseer) allows that such harm should be removed. This maxim is based on the injunctions of the Quran which are aimed at removing harj. Therefore, pain medication becomes a permissible option. However, this pain medication should be aimed at removing harm, not causing it. This is based on another juristic maxim "Harm shall be removed", (al-darar yuzal) as derived from the Hadith that "harm may neither be inflicted nor reciprocated in Islam" (la darar wa la dirar fil Islam). Therefore, it depends on the nature of intentionality of both the physician and the patient; if the right intentionality is present in both the physician and the patient that is aimed at removing the severe pain, it would turn pain medication into a permissible act. This is based on the other famous juristic maxim known as "Matters shall be judged by their objectives", (al-umur bi maqasidiha). This principle is without dispute applicable to almost all moral actions. This principle is well founded on the sound tradition of the Prophet in which he states: "Actions are but by intention and each person will have but that which he intended". However, one can argue on the basis of other maxims that state, "Harm must be eliminated but not by means of another harm" (ad-dararu yuzalu wa lakin la bi-darar); and "Harm is not eliminated by another harm" (ad-dararu la yuzalu bid-darar). Therefore, an injury should not be relieved by a medical procedure that leads to an injury of the same magnitude as a side effect, ( $A d$ dararu la yuzal bi mithlihi). And when choice is between two kinds of harm, the greater harm should be removed; it is based on another maxim, "A greater harm is eliminated by means of a lesser harm" (addararu al-ashadd yuzal bid-darar al-akhaff). In light of these maxims, it seems hastening death is a greater harm therefore removing small harm that causes it is not legitimized. Therefore, pain medication should not be permissible. However, rethinking these maxims while including other relevant maxims such as "Harm is eliminated to the extent that is possible" (al-darar yuzal bi-qadr al imkan) provides space for permissibility. Furthermore, since pain is unbearable therefore it creates a necessity and the maxim which applies to necessity is "Necessity makes the unlawful lawful" (al-darurat tubih al-mahzurat). And "pressing needs (hajat) are treated as necessities (daruriyyat)". However, the permission on the basis of necessity should not exceed the due proportion and limits of permissibility. Therefore, the necessity in case of pain medication has to be understood well and it should be applied to the legitimate and limited proportion; this insight is covered by other relevant maxim that states "Necessity is measured in accordance with its true proportions" (al-darurat tuqaddaru bi-qadriha). The principle of necessity that implies the permission of unlawful in necessary conditions is beside many verses of the Quran based on the verse from the chapter of the Cow (Al Baqara) which states: "He hath only forbidden you dead meat, and blood, and the flesh of swine, and that on which any other name hath been invoked besides that of Allah. But if one is forced by necessity, without wilful disobedience, nor transgressing due limits, then is he guiltless. For Allah is Oft- 
forgiving Most Merciful" ${ }^{41}$. In this verse, the necessity is conditioned with two conditions: the permissibility should not transgress due limits and it should not be a wilful disobedience.

In light of the above discussion based on the Quran and the legal maxims, it seems that statements and opinions made by Muslim scholars in favor for pain medication have justification in Islamic sources. Therefore, given pain medication to a patient is allowed even if it hastens death as a side effect as an unintended consequence. However, it would not be permissible if the pain medication transgresses the due proportions and limits such as overdosing, in such case it would be prohibited. To illustrate this limit, overdosing a patient with pain killers that will result in abrupt death would be prohibited. Furthermore, opinions which go against pain medication seem very unrealistic as they actually do not demonstrate realistic understanding of the levels of pain and its intensity that passes into the categories of "necessity" and "pressing need".

CONCLUSION: Pain medication is one of the responses to the mercy argument that is used by proponents of euthanasia, especially utilitarian ethicists. They argue that mercy killing should be allowed on the grounds of mercy. Among the trends and traditions that oppose mercy killing are Catholics and Muslims. They base their approach on religious grounds beside other ethical principles derived from religious sources by theologians and jurists. Islamic and Catholic traditions allow pain medication. Catholic approach to pain medication beside other reasons is in practical way treated as an application of principle of double effect. This principle with stipulated conditions allows pain medication even if it hastening death as an unintended consequence. The Islamic discourse on pain medication is between denial and acceptance of pain medication. Some statements of Muslim scholars prohibit it and some allow it. The resolution on the issue is sought by synthesizing the views and legal maims on the issue, which in conclusion provide justification for pain medication by considering pain as necessity and pressing need. However, such resolution allows pain medication to the limit and proportion that removes the pain and prohibits overdosing the patient with medication that may directly cause the death.

\section{REFERENCES}

1. Moreland JP, Geisler NL. The Life and Death Debate Moral Issues of Our Time Westport, CT: Praeger; 1990. p. 71.

2. Moreland JP, Geisler NL. The Life and Death Debate Moral Issues of Our Time Westport, CT: Praeger; 1990. p. 70.

3. Rachels J. More impertinent distinctions and a defense of active euthanasia. In: Norcross A, Steinbock B, editors. Killing and letting die 2ed. New York USA: Fordham University Press; 1994. p. 139 -55. P.146.

4. Chadwick R. Encyclopedia of Applied Ethics. San Diego, CA: Academic Press; 1998. p. 184.

5. Moreland JP, Geisler NL. The Life and Death Debate Moral Issues of Our Time Westport, CT: Praeger; 1990. p. 71.

6. Jacox A, Carr D, Payne R. New clinical-practice guidelines for the management of pain in patients with cancer. The New England Journal of Medicine 1994;330(9):651-5. 
7. Foot P. More impertinent distinctions and a defense of active euthanasia. In: Norcross A, Steinbock B, editors. Killing and letting die 2ed. New York USA: Fordham University Press; 1994. p. 267.

8. Glannon W. Biomedical Ethics. New York: Oxford University Press; 2005. p. 126.

9. Moreland JP, Geisler NL. The Life and Death Debate Moral Issues of Our Time Westport, CT: Praeger; 1990. p. 72.

10. Singleton J, McLaren S. Ethical Foundations of Health Care: Responsibilities in Decision Making. St. Louis, MO: Mosby; 1995. pp. 60-61.

11. Curran CE. Catholic Moral Theology in the United States: A History Washington, DC: Georgetown University Press; 2008. p. 54.

12. Aquinas T. Summa theologica 1947 [cited 2007 March 20]. Available from: http://www.assumption.edu/users/gcolvert/ summa/index.html

13. A.McIntyre. Doctrine of double effect. 2004 [cited 2006 January 25]; Available from: http://plato.stanford.edu/entries/double-effect/.

14. Moreland JP, Geisler NL. The Life and Death Debate Moral Issues of Our Time Westport, CT: Praeger; 1990. p. 72.

15. Ashley BM, Deblois JK, O'Rourke KD. Health Care Ethics: A Catholic Theological Analysis Washington, DC: Georgetown University Press; 2006. p. 54.

16. Curran CE. Catholic Moral Theology in the United States: A History Washington, DC: Georgetown University Press; 2008. p. 55.

17. Cohen-Almagor R. Language and reality at the end of life. Journal of Law, Medicine \& Ethics. 2000; 28(3):267-78.

18. Wanzer S, Federman D, Adelstein S, CKCassel, Cassem E, Cranford R, et al. The physician's responsibility toward hopelessly ill patients: A second look. In: Walter IJJ, Shannon TA, editors. Quality of life: The new medical dilemma: Paulist Press; 1990. p. 282-92. p. 287.

19. Medical Treatment. Majallat Majma' al-Fiqh 1992;3(7):563.

20. Al-Bukhari. Sahih al-Bukhari. (M. M. Khan, Trans.). Book: 70, Hadith : 545. Available from: http://www.searchtruth.com/hadith_books.php.

21. The International Islamic Code for Medical and Health Ethics The Islamic Organization for Medical Sciences (IOMS) 1981.

22. Hathout H. Medical Ethics Questions From the Audience During the Medical Ethics Symposium at ISNA Convention. Shahid Athar; 1997 [cited 2012 March 5]; Available from: http://www.freepctools.com/ethics.htm.

23. Islamic Medical Ethics Islamic Medical Association of North America, Committee IE.

24. Hathout H. Frequently asked Medical Ethics Questions. Islamic Medical Association of North America; [cited 20123 May]; Available from: http://www.isna.net/Leadership/pages/lslamicMedical-Ethics.aspx.

25. Islamic Code of Medical Ethics Available from: www.emro.who.int/morocco/docs/en/Islamic_Ethics.

26. Beauchamp TL, Childress JF. Principles of biomedical ethics. 5th ed. ed. Oxford: Oxford University Press; 2001.

27. The Quran, 17:33. 
28. The Quran, 4: 93.

29. The Quran, 4: 29.

30. The Quran, 5:2.

31. The Quran, 2:185.

32. The Quran, 5:6.

33. The Quran, 94:28.

34. The Quran, 22: 78.

35. Al-Bukhari. Sahih al-Bukhari. (M. M. Khan, Trans.). Book, 2 Hadith, 38. Available from: http://www.searchtruth.com/hadith_books.php.

36. Imam Ahmad bin Hanbal. Musnad al-Imam Ahmad. Vol. 3.

37. Al-Bukhari. Sahih al-Bukhari. (M. M. Khan, Trans.). Book 2, Hadith 38. Available from: http://www.searchtruth.com/hadith_books.php.

38. Al-Bukhari. Sahih al-Bukhari. (M. M. Khan, Trans.). Book 3, Hadith 69. Available from: http://www.searchtruth.com/hadith_books.php.

39. The Quran, 2:286.

40. Al-Bukhari. Sahih al-Bukhari. (M. M. Khan, Trans.). Book 1, Hadith 1. Available from: http://www.searchtruth.com/hadith_books.php.

41. The Quran, 2:173. 